\title{
PERBEDAAN PENYESUAIAN DIRI MAHASISWA DITINJAU DARI STRATEGI COPING
}

\section{DIFFERENCES OF UNIVERSITY STUDENTS' SELF-ADJUSTMENT VIEWED BY COPING STRATEGIES}

\author{
Putri Pusvitasari (1), Arini Mifti Jayanti ${ }^{(2)}$ \\ Program Studi Psikologi, Universitas Jenderal Achmad Yani Yogyakarta ${ }^{(1)}$, Program Studi Psikologi, \\ Universitas Jenderal Achmad Yani Yogyakarta ${ }^{(2)}$ \\ E-mail: putri.pusvitasari@unjaya.ac.id ${ }^{(1)}$, arinimiftijayanti@unjaya.ac.id ${ }^{(2)}$
}

\begin{abstract}
Abstrak : Tujuan dari penelitian ini adalah peneliti ingin mengetahui dan menguji secara empiris perbedaan penyesuaian diri mahasiswa ditinjau dari strategi coping. Selain kemampuan menyesuaikan diri yang dibutuhkan, pilihan strategi coping yang tepat juga dapat membantu mahasiswa untuk beradaptasi dengan lingkungan yang baru, aturan serta berbagai kegiatan di universitas tempat mereka melanjutkan studi. Peneliti menggunakan teknik purposive sampling, yaitu teknik penentuan sampel dengan pertimbangan tertentu yang diterapkan berdasarkan tujuan dari penelitian. Adapun subjek dalam penelitian ini adalah seluruh mahasiswa aktif tahun pertama Fakultas Ekonomi dan Sosial di Universitas Jenderal Achmad Yani Yogyakarta. Hasil pengumpulan data dari seluruh populasi 127 mahasiswa, berhasil dikumpulkan data penelitian sejumlah 65 sampel data subjek. Analisis data yang digunakan dalam penelitian ini adalah uji One Way Anova. Berdasarkan analisis data yang dilakukan, diketahui bahwa nilai F hitung sebesar 4,662 dengan signifikansi (p) sebesar 0,035 ( $\mathrm{p}<0,05)$. Hal ini dapat diartikan bahwa terdapat perbedaan penyesuaian diri mahasiswa ditinjau dari strategi coping stres yang dimilikinya.
\end{abstract}

Kata Kunci : Strategi Coping, Penyesuaian Diri, Mahasiswa

Abstract: The purpose of this study is researchers want to know and empirically test differences in student adjustment according to the coping strategy. In addition to the adaptability needed, the right choice of coping strategies can also help students to adapt to the new environment, rules and various activities at the university where they continue their studies. Researchers used a purposive sampling technique, which is a sampling technique with certain considerations applied based on the objectives of the study. The subjects in this study were all first year active students of the Faculty of Economics and Social at Jenderal Achmad Yani University, Yogyakarta. The results of data collection from a total population of 127 students, successfully collected research data totaling 65 sample data subjects. Analysis of the data used in this study was the One Way Anova. Based on data analysis, it is known that the calculated $F$ value of 4.662 with a significance ( $p$ ) of 0.035 ( $p<0.05)$. This can be interpreted that there are differences in the adjustment of students in terms of stress coping strategies they have.

Keywords: Adjustment, Coping Strategies, Students 


\section{PENDAHULUAN}

Masa remaja merupakan masa peralihan dari masa kanak-kanak yang mengalami perkembangan pada semua aspek atau fungsi untuk memasuki masa dewasa. Masa remaja, menurut Mappiare (Ali \& Asrori, 2009), berlangsung antara umur 12 tahun sampai dengan 21 tahun bagi wanita dan 13 tahun sampai dengan 22 tahun bagi pria. Remaja sedang mengalami perkembangan pesat dalam aspek intelektual. Sebagaimana yang diungkapkan oleh Shaw dan Costanzo (Ali \& Asrori, 2009) bahwa transformasi intelektual dari cara berpikir remaja memungkinkan mereka tidak hanya mampu mengintegrasikan dirinya ke dalam masyarakat dewasa, tetapi juga merupakan karakteristik yang paling menonjol dari semua periode perkembangan, sehingga tidak mengherankan jika usia remaja sangat diperhatikan.

Monks, Knoers, dan Haditono (2009) berpendapat bahwa remaja sebetulnya tidak mempunyai tempat yang jelas. Mereka sudah tidak termasuk golongan anak-anak, tetapi belum juga dapat diterima secara penuh untuk masuk ke golongan orang dewasa. Remaja ada di antara anak dan orang dewasa. Oleh karena itu, remaja seringkali dikenal dengan fase "mencari jati diri" atau fase "topan dan badai". Remaja masih belum mampu menguasai dan memfungsikan secara maksimal fungsi fisik maupun psikisnya. Namun, yang perlu ditekankan di sini adalah bahwa fase remaja merupakan fase perkembangan yang tengah berada pada masa yang amat potensial, baik dilihat dari aspek kognitif, emosi, maupun fisik.

Pada masa remaja, peran individu secara umum adalah sebagai seorang pelajar atau mahasiswa. Kehidupan tahun pertama di perguruan tinggi sebagai seorang mahasiswa cukup terasa perbedaannya setelah sebelumnya menyandang status sebagai siswa sekolah menengah. Mereka pada umumnya merasakan beberapa perubahan yang cukup menonjol di masa awal memasuki dunia perkuliahan ini. Kehidupan tahun pertama di perguruan tinggi sebagai mahasiswa cukup terasa perbedaannya setelah sebelumnya menyandang status sebagai siswa sekolah menengah. Mereka pada umumnya merasakan beberapa perubahan yang cukup menonjol di masa awal memasuki dunia perkuliahan ini. Gunarsa (2004) menyatakan bahwa individu yang baru saja beralih status menjadi mahasiswa mengalami perbedaan dalam hal sistem pendidikan perguruan tinggi. Hal ini meliputi sistem pengajaran, kedisiplinan, serta hubungan antara mahasiswa dengan dosen. Kemudian dalam hal akademik, perubahan juga terjadi pada hubungan mahasiswa dengan lingkungan sosialnya.

Sebagai mahasiswa, individu diharapkan dapat menjadi sumber daya manusia yang mempunyai intelektual yang tinggi, terampil, berpengetahuan, kreatif, serta menjadi tumpuan harapan dalam bersaing menghadapi era globalisasi yang semakin canggih ini. Individu tersebut juga diharapkan menghasilkan ide serta gagasannya untuk mengisi pembangunan yang nyata. Kondisi ini diperkuat kembali dengan hasil wawancara yang dilakukan terhadap beberapa orang mahasiswa Fakultas Ekonomi dan Sosial tahun pertama angkatan 2019 pada tanggal 12 Maret 2019 di Fakultas Ekonomi dan Sosial Universitas Jenderal Achmad Yani Yogyakarta. Mahasiswa tahun pertama dalam wawancara tersebut mengatakan bahwa ada perbedaan yang dirasakan ketika awal memasuki dunia perkuliahan. Perubahan tersebut meliputi sistem belajar, lingkungan pergaulan, serta kegiatan sehari-hari. Bahkan ada beberapa mahasiswa yang sebenarnya pada awalnya merasa ragu dan takut untuk melanjutkan kuliah. Mereka takut apabila tidak mampu untuk menyesuaikan diri dengan perubahan-perubahan tersebut.

Perbedaan dan perubahan yang dialami tersebut, apabila tidak diatasi dengan baik oleh mahasiswa tahun pertama dapat menyebabkan permasalahan, seperti menimbulkan perasaan tertekan pada diri individu (Thurber \& Walton, 2012). Hal ini juga terbukti dari hasil wawancara dengan mahasiswa Fakultas Ekonomi dan Sosial tahun pertama angkatan 2019. Beberapa dari mahasiswa tersebut menyebutkan bahwa mereka khawatir jika muncul rasa cemas dan takut akan perubahan yang terjadi pada tahun pertama perkuliahan ini sehingga berpengaruh pada proses kegiatan perkuliahan yang menjadi tidak optimal.

Wawancara tidak hanya dilakukan kepada mahasiswa saja, tetapi juga pada Dosen 
Pembimbing Akademik (DPA) yang sering berinteraksi dan bahkan menjadi tempat mahasiswa untuk berkonsultasi dan berkeluh kesah. Dari hasil wawancara ini didapatkan data bahwa beberapa mahasiswa pernah mengkonsultasikan permasalahan mereka terkait aktivitas akademik di awal masa perkuliahan. Mahasiswa tersebut mengaku bahwa dirinya merasa kurang percaya diri pada situasi yang baru sebagai mahasiswa, misalnya ketika ada tugas untuk presentasi di depan kelas, kemudian merasa kesulitan untuk berkomunikasi dengan teman ketika ada aktivitas berkelompok di kelas. Selain itu, ada juga mahasiswa yang merasa kesulitan untuk menyesuaikan diri dengan tuntutan dari dosen, misalnya sulit menyelesaikan tugas yang diberikan oleh dosen dengan tepat waktu akibat manajemen waktu yang buruk.

Untuk menghadapi situasi terkait perbedaan dan perubahan tersebut, maka mahasiswa dituntut untuk dapat menyesuaikan diri di perguruan tinggi agar dapat menguasai lingkungan sosial barunya, mengembangkan orientasinya terhadap institusi tempat dirinya berkuliah, menjadi anggota yang produktif dalam lingkup perguruan tinggi, dan menyesuaikan diri dengan peran serta tanggung jawab barunya (Gall, Evans, \& Bellerose, 2000).

Menurut Walgito (2003) penyesuaian diri merupakan kemampuan individu untuk meleburkan diri dalam lingkungan yang dihadapinya. Penyesuaian diri bisa diawali dengan stres atau perasaan tidak aman dimana setiap individu memberikan reaksi yang berbedabeda dalam menghadapi situasi tertentu sesuai dengan proses pendekatan yang digunakannya. Salah satu aspek dari penyesuaian diri yaitu adanya kemampuan untuk mengatasi perasaan frustasi pribadi. Perasaan frustasi pribadi yang tidak bisa diatasi akan membuat mahasiswa kesulitan dalam melakukan penyesuaian diri. Selain itu, kondisi individu yang stres terusmenerus karena ketidakmampuannya menyelesaikan masalahnya juga dapat mengakibatkan depresi (Sumiati, 2009).

Penyesuaian diri di perguruan tinggi merupakan sebuah respon psikososial pada diri mahasiswa dalam menanggapi perubahanperubahan yang terjadi di lingkungan sekitarnya, yang dapat menjadi sumber stres dan memerlukan serangkaian keterampilan coping
(Baker, McNeil, \& Siryk, 1985). Terdapat beberapa faktor penghambat penyesuaian diri mahasiswa baru berdasarkan penelitian Oetomo, Yuwanto, dan Rahayu (Yuwanto, 2019) yaitu faktor kecemasan akademik, kompetensi dan motivasi, hambatan fisik dan psikologis, pertemanan, serta keterbukaan dan kepercayaan diri. Berdasarkan pendapat tersebut, maka faktor penghambat penyesuaian diri pada mahasiswa baru perlu untuk diperhatikan. Pasalnya, agar dapat menyesuaikan diri dengan baik, maka dibutuhkan adanya perubahan persepsi bahwa kehidupan akademik di kampus bukan sebuah beban tetapi tantangan. Kemudian butuh pula relasi pertemanan yang baik sehingga mampu menghasilkan dukungan sosial dalam menjalani kehidupan akademik dan non akademik. Selain itu, pengelolaan diri juga sangat dibutuhkan oleh mahasiswa, yang meliputi pengaturan tujuan, target, proses belajar teratur, serta keterbukaan terhadap keberagaman.

Menurut Schneiders (2008), individu dengan penyesuaian diri yang tinggi memiliki ciri-ciri antara lain mampu beradaptasi, mampu berusaha mempertahankan diri secara fisik, mampu menguasai dorongan emosi, perilakunya menjadi terkendali dan terarah, motivasi tinggi dan sikapnya berdasarkan realitas. Sedangkan, individu dikatakan tidak mampu menyesuaikan diri apabila perasaan sedih, kecewa atau rasa putus asa berkembang dan mempengaruhi fungsifungsi fisiologi serta psikologisnya. Oleh karena itu, mahasiswa tahun pertama yang mampu melakukan penyesuaian diri dengan baik akan lebih mudah untuk berkembang secara optimal sesuai potensi yang dimilikinya sehingga tujuannya dalam menempuh pendidikan juga dapat tercapai. Hal ini sejalan pula dengan penelitian yang dilakukan oleh Crede dan Niehorster (2012), dimana penyesuaian diri yang baik di perguruan tinggi oleh mahasiswa tahun pertama berpengaruh dalam pencapaian akademik yang baik pula serta menghasilkan ketahanan mahasiswa dalam berkuliah.

Sejalan dengan perubahan-perubahan yang terjadi dalam kehidupan perkuliahan mahasiswa tahun pertama, setiap mahasiswa memiliki cara yang berbeda pula dalam mengatasi masalah atau tekanan dalam hidupnya. Selain kemampuan menyesuaikan diri yang dibutuhkan, pilihan strategi coping yang tepat juga dapat membantu 
mahasiswa untuk beradaptasi dengan lingkungan yang baru, aturan serta berbagai kegiatan di universitas tempat mereka melanjutkan studi. Strategi coping merupakan suatu cara atau metode yang dilakukan oleh tiap individu untuk mengatasi dan mengendalikan situasi atau masalah yang dialami dan dipandang sebagai hambatan, tantangan yang bersifat menyakitkan, serta yang merupakan ancaman yang bersifat merugikan (Aldwin \& Revenson, 1987). Strategi coping menunjuk pada berbagai upaya, baik mental maupun perilaku, untuk menguasai, mentoleransi, mengurangi suatu situasi atau kejadian yang penuh tekanan (Muslimah \& Aliyah, 2013).

Penelitian lain dilakukan oleh Sinaga (2005) tentang coping stres pada mahasiswa Fakultas Psikologi yang sedang menyusun skripsi. Pada penelitiannya diketahui bahwa mahasiswa yang mengalami stres akibat kesulitan dalam penyusunan skripsi sebanyak $84,3 \%$ melakukan problem focused coping dengan mempelajari cara-cara atau keterampilan-keterampilan yang baru, yang diyakini dapat mengubah situasi stres dan $15,65 \%$ melakukan emotional focused coping yaitu perilaku yang cenderung mengatur emosi atau mengatasi tekanan emosionalnya, berkaitan dengan situasi yang terjadi. Dan dari hasil penelitian Lasmono dan Pramadi (2003) menyebutkan bahwa pada budaya jawa, problem focused coping lebih sering digunakan untuk mengatasi tekanan/masalah.

Berdasarkan beberapa uraian yang telah dikemukakan di atas, maka pertanyaan penelitian yang dapat diajukan adalah "Apakah ada perbedaan Penyesuaian Diri ditinjau dari Strategi Coping pada Mahasiswa?". Oleh karena itu, dengan adanya pertanyaan di atas, maka peneliti tertarik untuk meneliti lebih lanjut mengenai "Perbedaan Penyesuaian Diri mahasiswa ditinjau dari Strategi Coping".

\section{METODE}

Pendekatan yang digunakan dalam penelitian ini adalah pendekatan kuantitatif, dengan jenis penelitian studi komparasi. Menurut Sugiyono (2014), desain penelitian komparasi merupakan penelitian yang membandingkan keadaan satu variabel atau lebih pada dua atau lebih sampel yang berbeda, atau dua waktu yang berbeda.

\section{Sampel}

Sampel dalam penelitian ini adalah seluruh mahasiswa aktif tahun pertama Fakultas Ekonomi dan Sosial di Universitas Jenderal Achmad Yani Yogyakarta yang terdiri dari Program Studi Psikologi, Hukum, Akuntansi dan Manajemen. Kemudian dari populasi dengan karakteristik tersebut diambil sebanyak 65 sampel data subjek berjenis kelamin pria dan wanita yang berusia $16-20$ tahun.

Teknik sampling yang digunakan dalam penelitian ini adalah purposive sampling yaitu metode pengambilan sampel yang dipilih dengan cermat sehingga relevan dengan struktur penelitian, dimana pengambilan sampel dengan mengambil sampel orang-orang yang dipilih oleh penulis menurut ciri-ciri spesifik dan karakteristik tertentu.

\section{Pengumpulan Data}

Variabel penyesuaian diri diukur dengan menggunakan skala yang disusun oleh Pratiwi (2017) berdasarkan karakteristik penyesuaian diri yang baik di perguruan tinggi dari dimensidimensi yang dikemukakan oleh Baker dan Siryk. Adapun dimensi penyesuaian diri yang disebutkan ada empat, yaitu penyesuaian akademik, penyesuaian sosial, penyesuaian personal-emosional, dan kelekatan terhadap institusi/ komitmen. Skala ini berbentuk skala Likert, dimana responden memberikan rating pada setiap pernyataan yang memiliki rentang pilihan jawaban 1-4. Skor diperoleh dari penjumlahan rating tersebut. Jumlah aitem dalam skala ini adalah 36 butir aitem dengan nilai reliabilitas sebesar 0,876 .

Sedangkan variabel strategi coping diukur dengan menggunakan skala strategi coping stres yang dibuat oleh Achmadin (2015) berdasarkan aspek Problem focused coping dan Emotional focused coping yang dikembangkan oleh Lazarus dan Folkman. Aspek problem focus coping meliputi, konfrontasi, mencari dukungan sosial, dan penyelesaian masalah yang terencana. Sedangkan aspek emotional focus coping 
meliputi, pengendalian diri, menjaga jarak, penilaian kembali secara positif, tanggung jawab, dan lari atau menghindar. Skala ini berbentuk skala guttman, yaitu dengan menggunakan pilihan A atau B yang jawabannya paling sesuai dengan jawaban diri sendiri dan tidak ada jawaban salah atau benar. Jumlah jawaban A dan B masing-masing akan dihitung. Jika jawaban A mendominasi, maka subjek dikatakan memiliki kategori strategi coping Problem Focused Coping. Kemudian jika jawaban B mendominasi, maka subjek dikatakan memiliki kategori strategi coping Emotional Focused Coping. Jumlah aitem dalam skala ini adalah 16 butir aitem dengan nilai reliabilitas sebesar 0,759 .

\section{Analisis Data}

Teknik analisis data yang digunakan dalam penelitian ini adalah uji One Way Anova dibantu dengan program SPSS versi 16.0. Analisis ini dilakukan untuk menguji hipotesis perbedaan penyesuaian diri ditinjau dari strategi coping pada mahasiswa aktif tahun pertama Fakultas Ekonomi dan Sosial di Universitas Jenderal Achmad Yani Yogyakarta.

\section{HASIL}

Subjek dalam penelitian ini berjumlah 65 orang. Mayoritas subjek berjenis kelamin perempuan, yaitu sejumlah 49 orang dengan persentase $75,4 \%$. Sedangkan subjek berjenis kelamin laki-laki sejumlah 16 orang dengan persentase $24,6 \%$. Sebagian besar subjek berasal dari prodi Psikologi yaitu sebesar $40 \%$. Sedangkan prodi lainnya, yaitu prodi Manajemen $(18,5 \%)$, prodi Hukum $(15,4 \%)$, dan prodi Akuntansi (26,1\%).

Strategi coping dibagi menjadi dua, yaitu problem focused coping dan emotional focused coping. Berikut jumlah dan persentase strategi coping yang telah dirangkum secara keseluruhan

Tabel 1. Jumlah dan presentase strategi coping

\begin{tabular}{llll}
\hline \multicolumn{2}{l}{ Problem Focused } & Coping & \multicolumn{2}{l}{ Emotional } & Focused Coping \\
\hline Frekuensi & Presentase & Frekuensi & Presentase \\
29 & $44,6 \%$ & 36 & $55,4 \%$ \\
\hline
\end{tabular}

Berdasarkan tabel di atas diketahui bahwa subjek sebanyak 29 orang menggunakan problem focused coping dengan presentase $44,6 \%$.
Sedangkan sebanyak 36 subjek menggunakan emotional focused coping dengan presentase $55,4 \%$. Sedangkan rangkuman jumlah dan presentase strategi coping berdasarkan jenis kelamin adalah sebagai berikut :

Tabel 2. Jumlah dan presentase strategi coping

\begin{tabular}{llll}
\hline \multicolumn{2}{l}{ Problem Focused Coping } & \multicolumn{2}{l}{ Emotional Focused Coping } \\
\hline Frekuensi & Presentase & Frekuensi & Presentase \\
29 & $44,6 \%$ & 36 & $55,4 \%$ \\
\hline
\end{tabular}

Berdasarkan tabel tersebut dapat diketahui secara keseluruhan bahwa emotional focused coping lebih dominan dimiliki oleh mahasiswa dibandingkan problem focused coping, baik itu yang berjenis kelamin perempuan maupun lakilaki. Berikut paparan hasil rata-rata skor penyesuaian diri pada kedua kelompok sampel tersebut:

Tabel 3. Deskripsi data skor penyesuaian diri

\begin{tabular}{|c|c|c|c|c|c|}
\hline & $\mathrm{N}$ & Min & Max & Mean & SD \\
\hline Problem & & & & & \\
\hline $\begin{array}{l}\text { Focused } \\
\text { Coping }\end{array}$ & 22 & 84 & 105 & 92,40 & 5,315 \\
\hline $\begin{array}{l}\text { Emotional } \\
\text { Focused } \\
\text { Coping }\end{array}$ & 43 & 80 & 104 & 90,82 & 4,615 \\
\hline
\end{tabular}

Berdasarkan tabel tersebut dapat diketahui bahwa rata-rata skor penyesuaian diri pada subjek dengan problem focused coping adalah sebesar 92,40 dengan nilai tertinggi 105 dan nilai terendah 84 serta standar deviasinya sebesar 5,315. Sedangkan subjek dengan emotional focused coping, nilai rata-ratanya sebesar 90,82, nilai terendah 80, nilai tertinggi 104 dan standar deviasinya sebesar 4,615. Berdasarkan nilai mean tersebut, maka dapat diketahui bahwa tingkat penyesuaian diri yang diperoleh yaitu terdapat 7 orang dengan problem focused coping memperoleh skor di atas rata-rata, dan 15 orang memperoleh skor di bawah rata-rata. Sedangkan pada subjek dengan emotional focused coping, terdapat 28 sampel yang memperoleh skor di atas rata-rata dan 15 sampel yang memiliki skor di bawah rata-rata.

Hasil Uji Asumsi

Uji normalitas pada penelitian ini dilakukan dengan menggunakan teknik One sample Kolmogorov-Smirnov test One sample Kolmogorov-Smirnov test. Kaidah yang 
digunakan yaitu jika $\mathrm{p}>0,05$, maka sebaran data tersebut normal, sedangkan $\mathrm{p}<0,05$, maka sebaran tersebut tidak normal. Hasil uji normalitas dari skala penyesuaian diri diperoleh Kolmogorov- $=0,862$ dan $\mathrm{p}=0,447(\mathrm{p}>0,05)$. Hal tersebut memiliki arti bahwa hasil skala penyesuaian diri terdistribusi secara normal.

Uji homogenitas dilakukan dengan tujuan untuk mengetahui perbedaan frekuensi atau proporsi antara variabel dalam satu kelompok yang diujikan. Kaidah uji homogenitas yang digunakan adalah jika nilai signifikansi (p) lebih dari 0,05 maka dapat dikatakan bahwa varian dari dua atau lebih kelompok data adalah sama atau homogen. Akan tetapi, jika $\mathrm{p}<0,05$ maka dapat disimpulkan bahwa sebaran data heterogen. Adapun uji homogenitas berdasarkan Levene's test skala penyesuaian diri menunjukkan nilai $\mathrm{F}=$ 0,199 dan $\mathrm{p}=0,657(\mathrm{p}>0,05)$. Hal tersebut menunjukkan bahwa data penyesuaian diri pada dua kelompok strategi coping homogen.

\section{Hasil Uji Hipotesis}

Kemudian hasil analisis yang telah dilakukan dengan menggunakan uji One Way Anova, dapat diketahui hasil sebagai berikut:

Tabel 4. Pengujian Hipotesis

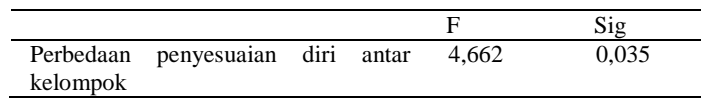

Berdasarkan hasil analisis uji anova di atas diperoleh harga $\mathrm{F}$ hitung sebesar 4,662 dengan signifikansi (p) sebesar 0,035 ( $<<0,05)$. Hal ini dapat diartikan bahwa terdapat perbedaan penyesuaian diri mahasiswa ditinjau dari strategi coping stres yang dimiliki. Berikut analisis means plot yang dapat terlihat dari grafik:
Gambar 1. Grafik posisi mean tiap kelompok

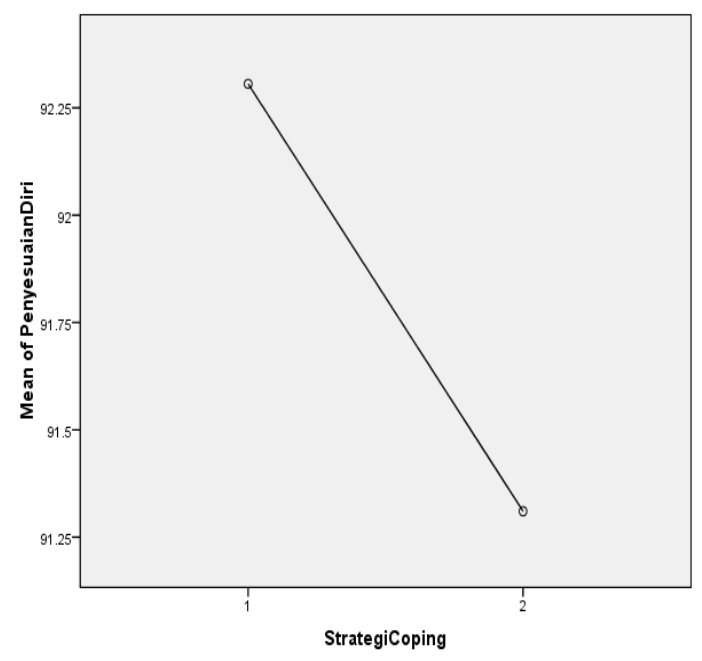

Berdasarkan grafik di atas kita dapat melihat posisi mean tingkat penyesuaian diri dari masingmasing kelompok strategi coping, yaitu problem focused coping (1) dan emotional focused coping (2). Arti dari grafik tersebut adalah mahasiswa yang cenderung menggunakan problem focused coping sebagai strategi coping memiliki tingkat penyesuaian diri yang tinggi (baik). Sedangkan sebaliknya, mahasiswa yang cenderung menggunakan emotional focused coping sebagai strategi coping memiliki tingkat penyesuaian diri yang rendah.

\section{DISKUSI}

Penelitian ini bertujuan untuk menguji hipotesis adanya perbedaan tingkat penyesuaian diri ditinjau dari dua strategi coping yang dimiliki oleh mahasiswa. Berdasarkan analisis One Way Anova, hipotesis tersebut dinyatakan diterima, dimana hasilnya menunjukkan adanya perbedaan tingkat penyesuaian diri ditinjau dari dua strategi coping yang dimiliki oleh mahasiswa dengan nilai signifikansi sebesar $0,035(\mathrm{p}<0,05)$. Selain itu, setelah dilakukan pengambilan data di lapangan juga diketahui bahwa terdapat 55,4 \% mahasiswa yang termasuk dalam kelompok yang menggunakan emotional focused coping sebagai strategi pemecahan masalahnya. Sedangkan sisanya yaitu $44,6 \%$ mahasiswa cenderung fokus menyelesaikan masalah dengan menggunakan strategi problem focused coping. 
Hasil penelitian di atas sejalan dengan penelitian serupa yang telah diteliti sebelumnya. Penelitian tersebut dilakukan oleh Kumala (2013) dengan judul Hubungan Strategi Coping dengan Penyesuaian Diri Mahasiswa Baru di Ma'had Sunan Ampel Al-Aly Universitas Islam Negeri (UIN) Maulana Malik Ibrahim Malang. Pada penelitian tersebut diketahui bahwa ada hubungan yang signifikan antara strategi coping dengan penyesuaian diri dengan nilai signifikansi sebesar 0,000. Kemudian didapatkan hasil pula dimana terdapat hubungan signifikan antara strategi coping jenis emotional focused coping dengan penyesuaian diri. Sedangkan untuk jenis problem focused coping tidak terdapat hubungan yang signifikan dengan variabel penyesuaian diri. Hasil ini menunjukkan bahwa mayoritas mahasiswa baru di Ma'had Sunan Ampel Al-Aly Universitas Islam Negeri (UIN) Maulana Malik Ibrahim Malang menggunakan emotional focused coping dalam menyesuaikan diri dibandingkan dengan strategi problem focused coping.

Sejalan dengan penelitian Kumala (2013), dimana ada lebih dari separuh subjek dalam penelitian ini yang menggunakan emotional focused coping dalam menghadapi masalah. Dengan emotional focused coping, mahasiswa akan cenderung untuk lebih memfokuskan diri dan melepaskan emosi yang berfokus pada kekecewaan ataupun distres yang dialami dalam rangka untuk melepaskan emosi atau perasaan tersebut. Beberapa tipe orang dengan emotional focused coping adalah melarikan diri dari masalah, mengabaikan permasalahan, dan menyalahkan diri sendiri atas masalah yang dialami.

Sedangkan kurang dari 50\% mahasiswa dalam penelitian ini memilih untuk menggunakan problem focused coping sebagai strategi yang tepat dalam penyelesaian masalah. Dengan problem focused coping, mahasiswa akan fokus berusaha untuk mencari dan menghadapi pokok permasalahan dengan cara mempelajari strategi atau keterampilan-keterampilan baru dalam rangkan mengurangi stresor yang dihadapi atau dirasakan. Hal ini ditandai dengan melakukan tindakan secara langsung yang berfokus pada masalah, memiliki sikap hati-hati dalam mengambil keputusan serta melakukan negosiasi dengan pihak yang terlibat langsung dalam permasalahan (Lazarus \& Folkman, 1984).

Setiap individu akan dihadapkan pada suatu masalah dalam hidup yang harus dihadapi dan diselesaikannya. Individu yang tidak mampu menghadapi dan menyelesaikan permasalahannya akan berada dalam kehidupan yang jauh dari kesejahteraan. Oleh karena itu, kemampuan coping yang tepat sangat diperlukan dalam menjalani kehidupan sehari-hari. Strategi coping menurut Lazarus dan Folkman (1984) merupakan cara yang tepat untuk mengelola, menerima, mentolerir, dan menyelesaikan masalah sehingga individu dapat beradaptasi dalam menghadapi konflik atau masalah yang dimilikinya.

Mahasiswa adalah individu yang mengalami banyak perubahan dalam hidupnya, agar dapat menjalani aktivitas, mencapai tujuan, dan memperoleh kesejahteraan maka mahasiswa diharapkan memiliki kemampuan penyesuaian diri yang baik. Berdasarkan hasil pengambilan data yang dilakukan di lapangan diketahui bahwa hanya $15,4 \%$ mahasiswa dari total subjek penelitian yang memiliki penyesuaian diri tinggi (baik). Sedangkan sisanya berada pada kategori penyesuaian diri sedang, bahkan rendah. Rendahnya tingkat penyesuaian diri pada mahasiswa ini merupakan indikasi adanya kesulitan dalam menyesuaikan diri dengan lingkungan sekitarnya. Kondisi ini merupakan sebuah permasalahan tersendiri yang dihadapi mahasiswa.

Pada penelitian ini beberapa mahasiswa mengaku bahwa dirinya merasa kurang percaya diri pada situasi yang baru sebagai mahasiswa, misalnya ketika ada tugas untuk presentasi di depan kelas, kemudian merasa kesulitan untuk berkomunikasi dengan teman ketika ada aktivitas berkelompok di kelas. Selain itu, ada juga mahasiswa yang merasa kesulitan untuk menyesuaikan diri dengan tuntutan dari dosen, misalnya sulit menyelesaikan tugas yang diberikan oleh dosen dengan tepat waktu akibat manajemen waktu yang buruk.

Schneiders (2008) mengungkapkan bahwa perbedaan tingkat penyesuaian diri antara satu orang dengan orang yang lainnya bisa disebabkan oleh beberapa faktor, diantaranya adalah kondisi fisik, kepribadian, proses belajar, lingkungan, dan agama. Penyesuaian diri ini juga sangat erat 
kaitannya dengan adanya perubahan yang terjadi di sekitar lingkungan. Seperti pada wawancara dengan salah satu mahasiswa yang menyebutkan bahwa ada perbedaan yang dirasakan ketika memasuki dunia perkuliahan. Perubahan tersebut meliputi sistem belajar, lingkungan pergaulan, serta kegiatan sehari-hari. Bahkan ada beberapa mahasiswa yang sebenarnya pada awalnya merasa ragu dan takut untuk melanjutkan kuliah. Mereka takut apabila tidak mampu untuk menyesuaikan diri dengan perubahan-perubahan tersebut. Perbedaan dan perubahan yang dialami tersebut, apabila tidak diatasi dengan baik oleh mahasiswa tahun pertama dapat menyebabkan permasalahan, seperti menimbulkan perasaan tertekan pada diri individu (Thurber \& Walton, 2012).

Menurut Rini dan Ghufron (2010), seseorang dikatakan memiliki penyesuaian diri yang baik apabila mencapai kepuasan dalam usahanya untuk memenuhi kebutuhannya, mengatasi ketegangan, bebas dari berbagai gejala yang mengganggu (seperti kecemasan, kemurungan, depresi, obsesi, atau gangguan psikosomatis yang dapat menghambat tugas seseorang), frustasi dan konflik. Berdasarkan pernyataan tersebut, maka dapat dikatakan bahwa seseorang dengan penyesuaian diri yang baik, akan cenderung berupaya untuk mengatasi segala macam tekanan dan permasalahan dengan cara yang tepat. Salah satu cara yang tepat adalah dengan fokus pada strategi problem focused coping, dimana individu akan fokus pada masalah yang dihadapi. Hal ini juga sejalan dengan apa yang diungkapkan oleh Kumala (2013) dimana setiap individu yang mampu memilih strategi coping untuk menyelesaikan permasalahannya dalam menyesuaikan diri, maka individu tersebut dapat dikatakan memiliki penyesuaian diri yang baik. Begitu pula sebaliknya, individu yang tidak mampu memilih strategi coping dalam menghadapi masalahnya, maka penyesuaian dirinya dapat dikatakan rendah atau kurang baik.

\section{KESIMPULAN}

Berdasarkan hasil analisis yang telah dilakukan, maka dapat disimpulkan bahwa terdapat perbedaan tingkat penyesuaian diri mahasiswa ditinjau dari strategi coping stres yang dimiliki. Mahasiswa yang cenderung menggunakan problem focused coping sebagai strategi coping memiliki tingkat penyesuaian diri yang tinggi (baik). Sedangkan sebaliknya, mahasiswa yang cenderung menggunakan emotional focused coping sebagai strategi coping memiliki tingkat penyesuaian diri yang rendah.

Saran: Implikasi dari penelitian ini adalah diharapkan agar para mahasiswa baru, sebelum memulai kegiatan perkuliahan di tahun pertama, dapat diberikan edukasi mengenai strategi coping yang tepat untuk mengatasi dan mengelola stres sehingga dapat memiliki penyesuaian diri yang baik dengan lingkungan sekitar kampus. Selanjutnya bagi peneliti yang akan melakukan penelitian dengan variabel terkait, sebaiknya memperhatikan variabel lain yang lebih meluas agar diperoleh gambaran penelitian yang lebih komprehensif.

\section{DAFTAR PUSTAKA}

Achmadin, A.J. (2015). Strategi coping stres pada mahasiswa baru Fakultas Psikologi Universitas Muhammadiyah Malang. Skripsi (tidak diterbitkan). Malang : Fakultas Psikologi Universitas Muhammadiyah Malang. http://eprints.umm.ac.id/34265/

Aldwin, C.M., \& Revenson, T.A. (1987). Does coping help? A reexamination of the relation between coping and mental healthy. Journal of Personality and Social Psychology, 53 (2), 337-348. DOI: 10.1037//0022-3514.53.2.337

Ali, M., Prof, Dr. \& Asrori, M., Prof, Dr. (2009). Psikologi Remaja: Perkembangan Peserta Didik. Jakarta: Bumi Aksara.

Baker, R.W., McNeil, O.V., \& Siryk, B. (1985). Expectation and reality in freshman adjustment to college. Journal of Counseling Psychology, 32 (1), 94. DOI: 10.1037/0022-0167.32.1.94

Crede, M., \& Niehorster, S. (2012). Adjustment to college as masured by the student adaptation to college questionnaire: A 
quantitative review of its structure and relationships with correlates and consequences. Educational Psychology Review, 24 (1), 133-165. DOI: 10.1007/s10648-011-9184-5

Gall, T.L., Evans, D.R., \& Bellerose, S. (2000). Transition to first-year university: Patterns of change in adjustment across life domains and time. Journal of Social and Clinical Psychology, 19 (4), 544567. DOI: $10.1521 /$ jscp.2000.19.4.544

Gunarsa, S. (2000). Psikologi Praktis: Anak, Remaja, dan Keluarga. Jakarta: PT. BPK Gunung Mulia.

Kumala, A.N. (2013). Hubungan strategi coping dengan penyesuaian diri mahasiswa baru di Ma'had Sunan Ampel al-Aly Universitas Islam Negeri (UIN) Maulana Malik Ibrahim Malang. Skripsi (tidak diterbitkan). Malang: Universitas Islam Negeri Maulana Malik Ibrahim. http://etheses.uin-malang.ac.id/1825/

Lasmono, H., \& Pramadi, A. (2003). Coping stres pada etnis Bali, Jawa, Dan Sunda. Anima, Indonesian Psychological Journal. $18 \quad$ (4), 326-340. http://www.anima.ubaya.ac.id/class/ope npdf.php?file=1359082924.pdf

Lazarus, R.S. \& Folkman, S. (1984). Stress, Appraisal, and Coping. New York: McGraw Hill, Inc.

Monks, F.J., Knoers, A. M. P., \& Haditono, S. R. (2009). Psikologi Perkembangan: Pengantar dalam Berbagai Bagiannya. Yogyakarta: Gajah Mada University Press.

Muslimah, A.I., \& Aliyah, S. (2013). Tingkat kecemasan dan strategi koping religius terhadap penyesuaian diri pada pasien HIV/AIDS Klinik VCT RSUD Kota Bekasi. Jurnal Soul, 6 (2). http://www.ejournalunisma.net/ojs/index.php/soul/article/vie $\mathrm{w} / 885$
Pratiwi, A.J. (2017). Hubungan antara locus of control internal dan penyesuaian diri di perguruan tinggi pada mahasiswa tahun pertama. Skripsi (tidak diterbitkan). Yogyakarta : Program Studi Psikologi Fakultas Psikologi Universitas Sanata Dharma. https://repository.usd.ac.id/11528/2/129 114105_full.pdf

Rini \& Ghufron. (2010). Teori-teori Psikologi. Yogyakarta: Ar-Ruz Media.

Schneiders, A.A. (2008). Personal Adjustment and Mental Health. New York: Holtt, Renehart and Winston Inc.

Sinaga, M.A. (2005). Coping stresss pada mahasiswa psikologi Salatiga. Skripsi (tidak diterbitkan). Salatiga : Fakultas Psikologi UKSW.

Sugiyono. (2014). Metode Penelitian Pendidikan Pendekatan Kuantitatif, Kualitatid, dan R\&D. Bandung: Alfabeta.

Sumiati. (2009). Kesehatan Jiwa Remaja \& Konseling. Jakarta : Trans Info Media.

Thurber, C.A., \& Walton, E.A. (2012). Homesickness and adjustment in university students. Journal of American College Health, 60 (5), 415-419. DOI: $10.1080 / 07448481.2012 .673520$

Walgito, B. (2003). Psikologi Sosial. Yogyakarta : Andi Yogyakarta.

Yuwanto, L. (2019). Faktor Penghambat Penyesuaian Diri Mahasiswa Baru. https://www.ubaya.ac.id/2018/content/ar ticles_detail/279/Faktor-PenghambatPenyesuaian-Diri-MahasiswaBaru.html. 9/1/2019 